\title{
PENGARUH BIAYA OPERASIONAL PENDAPATAN OPERASIONAL (BOPO), NON PERFORMING LOAN (NPL) DAN LOAN TO DEPOSIT RATIO (LDR) TERHADAP TINGKAT PROFITABILITAS PADA BPR KONVENSIONAL NTB LOMBOK TIMUR TAHUN 2013-2017
}

\section{Muhammad Amin}

Institut Pemerintahan Dalam Negeri Nusa Tenggara Barat. Email: aminlombok@gmail.com

\begin{tabular}{|c|c|}
\hline ARTICLE INFO & ABSTRACT \\
\hline $\begin{array}{l}\text { Keywords : } \\
\text { Burden Operate for to Earnings Of } \\
\text { Operation (BOPO), Non Performing Loan } \\
\text { (NPL), Loan To Deposit Ratio (LDR), Return } \\
\text { On Assets (ROA) } \\
\text { How to cite: } \\
\text { Amin, Muhammad. (2018). Pengaruh } \\
\text { Biaya Operasional Pendapatan } \\
\text { Operasional (Bopo), Non Performing Loan } \\
\text { (Npl) Dan Loan To Deposit Ratio (LDR) } \\
\text { Terhadap Tingkat Profitabilitas Pada } \\
\text { BPR Konvensional NTB Lombok Timur } \\
\text { Tahun 2013-2017, JMM UNRAM, 7(2), } \\
\text { 118 - 128 } \\
\text { DOI : } \\
\text { 10.29303/jmm.v7i2.388 }\end{array}$ & $\begin{array}{l}\text { At this research aim to to know what is there is influence } \\
\text { [among/between] Earnings of Oprasional and Burden } \\
\text { Operational (BOPO), Non Performing Loan (NPL) and of } \\
\text { Loan Deposit Ratio to (LDR) To Return On Asset (ROA) } \\
\text { at] Conventional BPR of Sub-Province Lombok island East } \\
\text { year 2013-2017. Population which is used in this research is all } \\
\text { conventional BPR of Lombok island year east sub-province } \\
\text { 2013-2017. By using method of Sampel Saturated, taken by } \\
\text { of sampel counted } 3 \text { bank which enlist in OJK. Technique } \\
\text { Analysis the used is doubled linear regresi, test classic } \\
\text { assumption covering test of normlitas, test autokorelasi., test } \\
\text { test and heteroskedastisitas of mult ikolinearitas. Afterwards } \\
\text { also test hypothesis use t- statistical to test coefficient of regresi } \\
\text { parsial, and also F- statistical to test influence by together with } \\
\text { level 5\% (0.05) } \\
\text { Penelitian ini bertujuan untuk mengetahui apakah ada } \\
\text { pengaruh antara Pendapatan Oprasional dan Beban } \\
\text { Operasional (BOPO), Non Performing Loan (NPL) dan } \\
\text { Loan to Deposit Ratio (LDR) Terhadap Return On Asset } \\
\text { (ROA) pada BPR Konvensional Kabupaten Lombok } \\
\text { Timur tahun 2013-2017. Populasi yang digunakan } \\
\text { dalam penelitian ini adalah semua BPR konvensional } \\
\text { kabupaten Lombok timur tahun 2013-2017. Dengan } \\
\text { menggunakan metode Sampel Jenuh, diambil sampel } \\
\text { sebanyak } 3 \text { bank yang terdaftar di OJK. Teknik analisis } \\
\text { yang digunakan adalah regresi linier berganda, } \\
\text { melakukan uji asumsi klasik (prasyarat) yang meliputi } \\
\text { uji normlitas, uji autokorelasi., uji heteroskedastisitas }\end{array}$ \\
\hline
\end{tabular}


dan uji multikolinearitas. Setelah itu juga uji hipotesis menggunakan t-statistik untuk menguji koefisien regresi parsial, serta F-statistik untuk menguji pengaruh secara bersama-sama dengan level 5\% (0.05).

Copyright @ 2018 JMM UNRAM. All rights reserved.

\section{PENDAHULUAN}

Pada dunia modern sekarang ini, pembangunan ekonomi suatu negara harus tetap di tingkatkan, Dimana penduduk juga semakin meningkat dan persaingan hidup semakin ketat. Dalam pembangunan prekonomian sangat diperlukan peran serta lembaga keuangan Seperti perbankkan. Perbankan merupakan salah satu sumber dana untuk semua sektor yang berhubungan dengan keuangan, seperti pada sektor pertanian, sektor pertambangan, sektor usaha perdagangan maupun sektor-sektor jasa lainnya, dalam rangka meningkatkan perekonomian suatu negara (Hasan,2014:2).

Menurut Undang -Undang RI No. 10 tahun 1998 tentang perbankkan bahwa bank adalah "badan usaha yang menghimpun dana dari masyarakat dalam bentuk simpanan, dan menyalurkannya kembali dalam bentuk kredit dalam rangka meningkatkan taraf hidup rakyat banyak." Namun dalam prakteknya, bank juga merupakan suatu badan usaha yang bertujuan untuk mendapatkan keuntungan dari pembebanan bunga yang sudah di tentukan. Dari segi pungsinya jenis bank terdiri dari bank umum dan bank perkreditan rakyat (BPR), dimana bank umum adalah bank yang melaksanakan kegiatan usahanya secara komvensional, dalam kegiatannya memberikan jasa dalam lalu lintas pembayaran. Bank perkreditan rakyat (BPR) adalah bank yang melaksanakan kegiatan usahanya secara komvensional yang dalam kegiatannya tidak memberikan jasa dalam lalu lintas pembayaran (Kasmir,2014:33).

Setiap bank senantiasa menjaga kinerjanya dengan baik, terutama dalam menjaga dan mempertahankan tingkat profitabilitas yang tinggi, ini dapat di ukur melalui laporan keuangan bank. Analisis Laporan keuangan akan membantu pihak- pihak yang berkepentingan dalam memilih dan mengevaluasi informasi dengan perhatian terfokus pada informasi yang reliable dan relevan dengan keputusan bisnis, maka dapat menghemat waktu dan biaya perolehan informasi (Munawir, 2004). Berdasarkan laporan keuangan akan dapat dihitung sejumlah rasio keuangan yang lazim dijadikan dasar penilaian tingkat kesehatan bank. Analisis rasio keuangan memungkinkan pihak manajemen untuk mengidentifikasikan perubahan perubahan yang terjadi.

Keberhasilan perbankkan dapat di ukur dengan pendekatan rasio keuangan salah satunya profitabilitas. Menurut Kasmir, (2014:113), "Profitabilitas" adalah kemampuan suatu perbankkan untuk mendapatkan keuntungan (profit) secara keseluruhan". Dalam penelitian profitabilitas biasanya menggunakan rasio Return On Asset (ROA), karena ROA memfokuskan kemampuan manajemen bank dalam menghasilkan income dari pengelolaan asset yang dimiliki. Seperti yang dikemukakan oleh Dendawijaya (2009:119) bahwa: “Dalam mengukur tingkat kesehatan bank, Bank Indonesia lebih mementingkan penilaian besarnya ROA dan tidak memasukan unsur ROE. Hal ini dikarenakan Bank Indonesia sebagai pembina dan pengawas perbankan lebih mengutamakan nilai profitabilitas suatu bank yang diukur dengan asset yang dananya sebagian besar berasal dari dana pihak ketiga.Profitabilitas mencerminkan kemampuan bank dalam menghasilkan laba melalui kegiatan operasional yang dilakukannya, 


\section{NATIONALLY ACCREDITED J OURNAL - DECREE NO. 21/E/KPT/2018}

dimana Tingkat profitabilitas yang tinggi menunjukkan tingkat efisiensi suatu perbankkan yang sehat (Prilliana, 2012:36).

Dalam mengukur tingkat ROA dapat di bandingkan dengan berbagai rasio keuangan di antaranya Biaya Operasional da Pendapatan Operasional (BOPO), Non Performing Loan (NPL) dan Loan On Deposit Ratio (LDR). BOPO merupakan rasio antara biaya operasional terhadap pendapatan operasional. Setiap peningkatan biaya operasional akan berakibat pada berkurangnya laba sebelum pajak yang pada akhirnya akan menurunkan laba atau profitabilitas (ROA) bank yang bersangkutan. (Dendawijaya:2003).

NPL merupakan rasio untuk mengukur kemampuan bank dalam menjaga resiko kegagalan pengembalian kredit oleh debitur. jika kredit bermasalah meningkat maka akan menurunkan profitabilitas bank dan sebaliknya, (Dendawijaya, 2003).

Loan to Deposit Ratio (LDR), yaitu seberapa besar dana bank yang disalurkan kepada kreditur. Semakin tinggi Loan to Deposit Ratio (LDR) maka laba bank semakin meningkat (dengan asumsi bank tersebut mampu menyalurkan kreditnya dengan efektif).

Berikut ini table rasio-rasio keuangan pada BPR Komvensional

Tabel 1

Rasio Keuangan

PD.BPR NTB Lombok Timur Periode 2013-2017

\begin{tabular}{|c|c|c|c|c|c|}
\hline RASIO & 2013 & 2014 & 2015 & 2016 & 2017 \\
\hline BOPO & $83,4 \%$ & 67,10 & 65,34 & 58,17 & $66,65 \%$ \\
\hline NPL & $1,75 \%$ & $2,25 \%$ & $2 \%$ & $3 \%$ & $4 \%$ \\
\hline LDR & $134 \%$ & $142, \%$ & $150, \%$ & $168, \%$ & 172,88 \\
\hline ROA & $2,23 \%$ & $4,83 \%$ & $4,45 \%$ & 5,167 & $4,16 \%$ \\
\hline
\end{tabular}

Tabel 2

Rasio Keuangan

BPR Segara Anak Kencana Aikmel Periode

2013-2017

\begin{tabular}{|c|c|c|c|c|c|}
\hline RASIO & 2013 & 2014 & 2015 & 2016 & 2017 \\
\hline BOPO & 88,49 & 88,38 & 83,92 & 86,46 & 81,22 \\
\hline NPL & $2,80 \%$ & $3,20 \%$ & $4,50 \%$ & $6,50 \%$ & $5 \%$ \\
\hline LDR & 65,76 & 65.22 & 66,97 & 65,95 & 62,05 \\
\hline ROA & $2,26 \%$ & $2,19 \%$ & $1,82 \%$ & $1,67 \%$ & $1,79 \%$ \\
\hline
\end{tabular}

Tabel 3

Rasio Keuangan

BPR Samas Masbagek Periode 2013-2017

\begin{tabular}{|c|c|c|c|c|c|}
\hline RASIO & 2013 & 2014 & 2015 & 2016 & 2017 \\
\hline BOPO & 93,12 & 89,60 & 89,75 & 80,94 & 90,93 \\
\hline NPL & $2,70 \%$ & $3,30 \%$ & $1 \%$ & $1 \%$ & $1 \%$ \\
\hline LDR & $140, \%$ & $145, \%$ & $150, \%$ & $131, \%$ & $129, \%$ \\
\hline ROA & $2,03 \%$ & $4,24 \%$ & $2,73 \%$ & $4,58 \%$ & $1,42 \%$ \\
\hline
\end{tabular}

Rasio BOPO pada PD.BPR NTB Lombok Timur pada periode tahun 2016-2017 mengalami kenaikan sebesar 8,48\%, dan dikuti dengan penurunan rasio ROA sebesar $1 \%$. Hal 
ini sesuai dengan teori dimana jika BOPO mengalami kenaikan, maka ROA akan menurun dan sebaliknya. Tetapi lain halnya pada BPR Segara Anak Kencana ahun 2012-2015 mengalami penurunan sebesar 5,24\% di ikuti dengan penurunan ROA sebesar 0,37\%. Ini bertolak belakang dengan teori Jika BOPO menurun maka ROA meningkat. Pada BPR Samas mengalami kenaikan sebesar 9,99\% dan ROA mengalami penurunan sebesar 3,13\%. Hal ini sesuai dengan teori dimana jika BOPO mengalami kenaikan, maka ROA akan menurun dan sebaliknya. Hal ini menandakan bahwa ketiga bank tersebut mengalami Rasio Non Performing Loan (NPL) pada PD.BPR NTB Lombok Timur pada periode tahun 2016-2017 mengalami kenaikan sebesar $1 \%$, akan tetapi rasio ROA mengalami penurunan sebesar $1,07 \%$. Pada BPR Segara Anak Kencana mengalami penurunan sebesar 1.50\% dan ROA mengalami penurunan sebesar 3,9\%, pada BPR Samas tidak mengalami perubahan, tetapi ROA mengalami penurunan. Hal ini bertentangan dengan teori dimana jika NPL menurun profitabilitas (ROA) meningkat.

Loan to Deposit Ratio (LDR), yaitu seberapa besar dana bank yang disalurkan kepada kreditur. Semakin tinggi Loan to Deposit Ratio (LDR) maka laba bank semakin meningkat (dengan asumsi bank tersebut mampu menyalurkan kreditnya dengan efektif). Rasio LDR pada PD.BPR NTB Lombok Timur pada tahun 2016-2017 mengalami kenaikan sebesar 4,32\% akan tetapi rasio ROA mengalami penurunan sebesar 1,07\%. Pada BPR Segara Anak Kencana NPL mengalami penurunan sebesar 3,9\% dan ROA mengalami kenaikan sebesar 0,12\%. Pada BPR Samas LDR mengalami penurunan sebesar 2.48\% dan ROA mengalami penurunan sebesar $3,16 \%$. Hal ini tidak sesuai dengan teori dimana jika LDR mengalami kenaikan, maka ROA juga akan mengalami kenaikan dan jikan LDR mengalami penurunan maka ROA juga mengalami penurunan.

\section{LANDASAN TEORI}

Bank merupakan lembaga keuangan yang memiliki peran penting bagi aktivitas perekonomian. Peran strategis tersebut adalah sebagai perantara antara masyarakat yang memerlukan dana dengan masyarakat yang kelebihan dana. Seperti yang tercantum pada Undang-Undang No. 10 Tahun 1998 menyatakan "Bank adalah badan usaha yang menghimpun dana dari masyarakat dalam bentuk simpanan dan menyalurkannya kepada masyarakat dalam bentuk kredit dan atau bentuk bentuk lainnya dalam rangka meningkatkan taraf hidup rakyat banyak.

Rasio merupakan salah satu metode analisis untuk menilai atau mengukur kondisi keuangan dan kinerja suatu perbankkan dengan menggunakan perhitungan-perhitungan rasio atas dasar kuantitatif, yang menunjukkan hubungan antara suatu unsur dengan unsur lainnya dalam laporan keuangan (Djarwanto 1996:123).

Jenis - Jenis Rasio Keuangan sebagai berikut:

a. Rasio likuiditas adalah rasio-rasio yang dimaksudkan untuk mengukur likuiditas atau kemampuan perbankan dalam melunasi kewajiban jangka pendek (current ratio, acid test ratio).

b. Rasio leverage adalah rasio-rasio yang dimaksudkan untuk mengukur sampai seberapa jauh aktiva perusahaan dibiayai dengan utang (debt to total assets ratio, net worth to debt ratio dan sebagainya).

c. Rasio aktivitas adalah rasio-rasio yang dimaksudkan untuk mengukur sampai seberapa besar efektivitas perusahaan dalam mengerjakan sumber - sumber dananya (inventory 
turnover, average collection period, dan sebagainya).

d. Rasio profitabilitas atau disebut juga rasio rentabilitas yang merupakan kemampuan perusahaan mendapatkan laba melalui semua kemampuan, dan sumber yang ada se perti kegiatan penjualan, kas, modal, jumlah karyawan, dan sebagainya. (Return on asset, Return on equity,Non performingloan, Loan to deposit ratio, CAR, BOPO)

Profitabilitas yang diasumsikan kan kedalam ROA merupakan indikator penting dalam menentukan tingkat kesehatan bank. Dimana kegiatan bisnis bank dapat dikatakan berhasil apabila mencapai profitabilitas yang tinggi. Menurut Sartono (2008:113) menyatakan bahwa: "Profitabilitas (ROA) adalah kemampuan perusahaan memperoleh laba dalam hubungan dengan penjualan, total aktiva maupun modal sendiri. Dengan demikian profitabilitas dapat digunakan sebagai salah satu alat untuk mengukur dan mengevaluasi kinerja bank dalam penggunaan asset yang dimiliki. Selain itu profitabilitas mengukur tingkat kembalian investasi yang telah dilakukan oleh bank, baik dengan menggunakan total aktiva yang dimiliki oleh bank maupun dana yang dimiliki oleh pemilik.

Menurut PSAK 31 (revisi 2009), bahwa: “Kredit bermasalah merupakan kredit yang pembayaran angsuran pokok dan bunganya telah lewat sembilan puluh hari atau lebih setelah jatuh tempo. Sedangkan menurut Rivai dan Veithzal (2005:4) Non Performing Loan merupakan kredit yang mengalami kesulitan dalam penyelesaian kewajiban-kewajibannya, baik dalam bentuk pembayaran kembali pokoknya atau pembayaran bunga, denda keterlambatan serta ongkos - ongkos bank yang menjadi beban nasabah yang bersangkutan."

LDR merupakan ukuran likuiditas yang mengukur besarnya dana yang ditempatkan dalam bentuk kredit yang berasal dari dana yang dikumpulkan oleh bank (terutama dana masyarakat). Salah satu penilaian likuiditas bank adalah dengan menggunakan rasio Loan to Deposit Ratio (LDR). Menurut Kasmir (2004:272), rasio LDR merupakan rasio perbandingan antara jumlah dana yang disalurkan ke masyarakat (kredit) dengan jumlah dana masyarakat yang digunakan.

\section{METODE PENELITIAN}

Dalam penelitian ini peneliti menggunakan jenis kuantitatif, dimana data yang diperoleh nantinya berupa angka. Dari angka yang diperoleh akan dianalisis lebih lanjut dalam analisis data (Sugiyono, 2011:7). Ada tiga variable dalam penelitian ini, bopo(X1), Non Performing oan (X2) dan loan to deposito ratio(LDR) (X3) sebagai variable indevenden dan Tingkat Profitabilitas (Y) sebagai variabel devenden.

Jenis data yang digunakan dalam penelitian ini adalah data sekunder bersifat kuantitatif yaitu data rasio - rasio keuangan bank yang berasal dari laporan keuangan publikasi bank berupa angka. Rasio - rasio yang digunakan antara lain : Biaya Operasional terhadap Pendapatan Operasional (BOPO), Non Performing Loan (NPL)), dan Loan to Deposit Ratio (LDR), serta Return on Assets (ROA) yang mencerminkan kinerja bank. Data tersebut diambil dari tahun 2011 sampai dengan tahun 2015 yang diperoleh dari publikasi laporan keuangan tahunan perbankan dari website OJK.

Analisis regresi ganda adalah analisis yang digunakan peneliti untuk menentukan bagaimana keadaan (naik turunnya) variabel dependen (kriterium), bila dua (2) atau lebih variabel independen sebagai faktor predictor dimanipulasi (dinaik turunkan nilainya) Sugiyono (2013). Jadi analisis regresi ganda akan dilakukan bila jumlah variabel independennya minimal 2. 
Bentuk persamaan dapat dirumuskan sebagai berikut:

$Y=a+\beta_{1} X_{1}+\beta_{2} X_{2}+\beta_{3} X_{3}+e$

Dimana :

$\mathrm{Y}=$ profitabilitas

$\mathrm{a}=$ Konstanta

$\mathrm{X}_{1}=$ BOPO $\mathrm{X}_{2}=\mathrm{NPL} \mathrm{X}_{3}=\mathrm{LDR}$

$\beta=$ Koefisien regresi

$\mathrm{e}=$ error

Uji $\mathrm{t}$ digunakan untuk mengetahui pengaruh masing - masing varabel independen (BOPO, NPL, dan LDR) terhadap variabel dependen (Profitabilitas). Pengujian t dilakukan dengan membandingkan $\mathrm{t}$ hitung dengan $\mathrm{t}$ table. Jika $\mathrm{t}$ hitung lebih besar dari $\mathrm{t}$ tabel pada tingkat kepercayaan 95\% atau ( $\mathrm{p}$-value < 0,05), maka Ha diterima, yang artinya variabel independen yang diuji secara parsial mempunyai pengaruh terhadap variabel dependen. Perhitungan uji $\mathrm{t}$ dalam penelitian ini digunakan untuk menguji signifikansi dari hubungan BOPO,NPL,dan LDR terhadap variabel dependen Profitabilitas.

Uji f untuk mengetahui apakah semua variabel independen mampu menjelaskan variabel dependennya, maka dilakukan uji hipotesis secara simultan dengan menggunakan uji statistik f.

Dalam uji $F$ tingkat signifikan yang digunakan dalam penelitian ini adalah 0,95 atau $95 \%$ dengan $\alpha=0,05$ artinya kemungkinan dari hasil kesimpulan adalah benar mempunyai pengaruh BOPO, tingkat non performing loan, dan loan to deposit ratio sebesar $95 \%$ atau toleransi kesalahan sebesar 5\%, dan derajat kebebasan digunakan untuk menentukan $F_{\text {tabel. }}$

\section{HASIL DAN PEMBAHASAN}

Tabel 4

Descriptive Statistics

\begin{tabular}{|l|r|r|r|r|r|}
\hline & N & Min & Max & Mean & $\begin{array}{c}\text { Std. } \\
\text { Deviation }\end{array}$ \\
\hline BOPO & 15 & 58 & 93 & 80.40 & 10.973 \\
\hline NPL & 15 & 1 & 6 & 2.67 & 1.543 \\
\hline LDR & 15 & 62 & 172 & 118.93 & 41.450 \\
\hline ROA & 15 & 1 & 5 & 2.60 & 1.404 \\
\hline $\begin{array}{l}\text { Valid N } \\
\text { listwis }\end{array}$ & 15 & & & & \\
\hline
\end{tabular}

Jumlah data yang digunakan dalam penelitian ini sebanyak 15 data yang diteliti selama periode 2013-2017. Berdasarkan hasil perhitungan di atas dapat diketahui bahwa nilai BOPO tertinggi (Maximum) sebesar 93 dan nilai BOPO terendah (minimum) sebesar 58. Standar deviasi sebesar 10,973 lebih kecil dibandingkan dengan nilai mean (rata-rata) yaitu sebesar 80,40 berarti pernyataan BOPO dapat dikatakan relatif baik. 


\section{NATIONALLY ACCREDITED J OURNAL - DECREE NO. 21/E/KPT/2018}

Rasio Non Performing Loan (NPL) tertinggi (Maximum) sebesar 6 dan nilai NPL terendah (Minimum) sebesar 1. Nilai standar deviasi sebesar 1,543 lebih kecil dibandingkan dengan nilai mean (rata-rata) yaitu sebesar 2,67, sehingga simpangan data pada variabel NPL ini dapat dikatakan baik.

Loan Deposit Ratio (LDR) tertinggi sebesar172 dan nilai LDR terendah sebesar 62. Nilai standar deviasi sebesar 41,450 lebih kecil r dibandingkan dengan nilai mean (rata-rata) yaitu sebesar 118,93 sehingga pernyataan data pada variabel LDR ini dapat dikatakan baik.

Rasio Return On Asset (ROA) tertinggi sebesar 5 dan nilai terendahnya sebesar 1. Nilai standar deviasinya sebesar 1.404. Lebih kecil dibandingkan jumlah mean (rata-rata) sebesar 2,60 dan Hal ini menunjukkan bahwa pernyataan data ROA dapat dikatakan baik.

\subsection{Hasil Uji Asumsi Klasik}

\subsubsection{Uji Normalitas}

\section{Tabel 5}

One-Sample Kolmogorov-Smirnov Test

\begin{tabular}{|ll|r|r|r|r|}
\hline & & BOPO & NPL & LDR & ROA \\
\hline $\mathrm{N}$ & & 15 & 15 & 15 & 15 \\
Normal & Mean & 80.40 & 2.67 & 118.93 & 2.60 \\
Parameters ${ }^{\mathrm{a}}$ Std. Deviation & 10.973 & 1.543 & 41.450 & 1.404 \\
& Absolute & .219 & .200 & .263 & .265 \\
Most & Positive & .156 & .200 & .233 & .265 \\
Extreme & & -.219 & -.140 & -.263 & -.241 \\
Differences & Negative & .847 & .776 & 1.017 & 1.028 \\
& Kolmogorov- Smirnov Z & .469 & .583 & .252 & .241 \\
\hline
\end{tabular}

Penentuan Pengambilan Keputusan :

Jika Sig > 0,05 maka data berdistribusi normal

Jika Sig < 0,05 maka data tidak berdistribusi normal

Dari tabel di atas diketahui nilai Sig untuk ROA adalah 0,241 lebih besar dari 0,05 $(0,241>0,05)$ sehingga data berdistribusi normal. Sig BOPO adalah 0,469 lebih besar dari 0,05 $(0,469>0,05)$, sig NPL adalah 0,583 lebih besar dari 0,05 $(0,583>0,05)$ dan nilai sig untuk LDR adalah 0,252 sehingga data berdistribusi normal. Jadi data di atas dapat di simpulkan bahwa semua variable berdistribusi normal. 


\subsubsection{Uji Autokorelasi}

Tabel 7

Uji Autokorelasi

Model Summaryb

\begin{tabular}{|l|c|c|c|c|c|}
\hline Model & $\mathrm{R}$ & R Square & $\begin{array}{l}\text { Adjusted R } \\
\text { Square }\end{array}$ & $\begin{array}{c}\text { Std. Error of } \\
\text { the Estimate }\end{array}$ & $\begin{array}{l}\text { Durbin- } \\
\text { Watson }\end{array}$ \\
\hline 1 & .843 & .711 & .632 & .851 & 2.527 \\
\hline
\end{tabular}

Dari tabel di atas dapat diketahui jumlah variabel independen $(K)=3$ dan jumlah data $(\mathrm{N})=15$ dan nilai durbin watson $(\mathrm{D}-\mathrm{W})=2,527$ nilai batas bawah $\mathrm{dl}=0,8140 \mathrm{du}=1,7501$ maka $(4-0,8140)=3,186$ dan $(4-1.7501)=2,2499$ maka nilai autokorelasi di antara $(\mathrm{du}<\mathrm{dw}<4-\mathrm{du})$ atau $2499<2.527<3,186$ maka tidak terjadi autokorelasi dan tidak terjadi kesalahan data pada priode lalu yang mempengaruhi kesalahan data pada priode sekarang.

\subsection{Hasil Pengujian Hipotesis}

Tabel 6

Uji Parsial Uji (t)

\section{Coefficientsa}

\begin{tabular}{|r|r|r|r|r|r|}
\hline & $\begin{array}{r}\text { Unstandardized } \\
\text { Coefficients }\end{array}$ & $\begin{array}{r}\text { Standardized } \\
\text { Coefficients }\end{array}$ & & \\
\cline { 2 - 5 } Model & B & Std. Error & Beta & T & Sig. \\
\hline $1 \begin{array}{r}\text { (Cons } \\
\text { tant) }\end{array}$ & 6.317 & 3.112 & & & \\
BOPO & -.066 & .026 & & 2.030 & .067 \\
NPL & -.067 & .188 & -.517 & -2.506 & .029 \\
LDR & .015 & .008 & -.073 & -.355 & .729 \\
\hline
\end{tabular}

Uji Parsial (t) digunakan untuk mengetahui variabel independen (BOPO, NPL, dan LDR) apakah secara parsial berpengaruh signifikan atau tidak terhadap variable dependen (ROA). Berdasarkan tabel 4.8 hasil analisis regresi linier berganda menunjukkan hasil uji statistik $t$ antara variabel independen dengan variabel dependen sebagai berikut:

\section{a. Hasil Uji Hipotesis 1 : Pengaruh BOPO terhadap ROA}

Tabel 4.4 menunjukkan bahwa variable BOPO memiliki koefisien regresi negatif sebesar 0,066 dengan tingkat signifikansi sebesar 0,029. Tingkat signifikansi tersebut lebih kecil dari $0,05(-0,029<0,05)$ dan nilai t-hitung lebih besar dari t-tabel $(2.056>2,20099)$. Dengan demikian, dapat disimpulkan bahwa BOPO berpengaruh Negatif dan signifikan terhadap ROA. 


\section{NATIONALLY ACCREDITED J OURNAL - DECREE NO. 21/E/KPT/2018}

\section{b. Hasil Uji Hipotesis 2 : Pengaruh NPL terhadap ROA}

Tabel 4.4 menunjukkan bahwa variable NPL memiliki koefisien regresi negatif sebesar 0,067 dengan tingkat signifikansi sebesar 0.729. Tingkat signifikansi tersebut lebih besar dari 0,05 $(0,729>0,05)$. dan nilai t-hitung lebih kecil dari t-tabel $(-0,355<2,20099)$. Dengan demikian, dapat disimpulkan bahwa NPL secara parsial tidak berpengaruh dan tidak signifikan terhadap ROA.

\section{c. Hasil Uji Hipotesis 3 : Pengaruh LDR terhadap ROA}

Tabel 4.4 menunjukkan bahwa variable LDR memiliki koefisien regresi Positif sebesar 0,015 dengan tingkat signifikansi sebesar 0,036 lebih kecil dari 0,05 $(0,036<0,05)$ dan nilai t-hitung lebih besar dari t- tabel $(2,887>2,20099)$. Dengan demikian, dapat disimpulkan bahwa LDR secara parsial berpengaruh positif dan signifikan terhadap ROA.

Dari uraian di atas dapat disimpulkan bahwa variabel BOPO Secara parsial berpengaruh Negatif terhadap ROA. Sedangkan Rasio NPL tidak berpengaruh dan tidak signifikan terhadap ROA. Tetapi variable LDR berpengaruh Positif terhadap ROA.

Tabel 8

Uji Simultan (Uji F)

ANOVA $^{\text {b }}$

\begin{tabular}{|l|r|r|r|r|r|}
\hline Model & $\begin{array}{r}\text { Sum of } \\
\text { Squares }\end{array}$ & Df & $\begin{array}{c}\text { Mean } \\
\text { Square }\end{array}$ & F & Sig. \\
\hline $\begin{array}{l}1 \text { Regressi } \\
2 \text { On }\end{array}$ & 19.628 & 3 & 6.543 & 9.028 & $.003^{\mathrm{a}}$ \\
$\begin{array}{l}\text { Residual } \\
\text { Total }\end{array}$ & 27.972 & 11 & .725 & & \\
\hline
\end{tabular}

Berdasarkan tabel 4.9 dapat di ketahui bahwa hasil uji statistik $\mathrm{F}$ menunjukkan nilai signifikansi lebih kecil dari 0,05 yaitu 0,003 <0,05. Dengan df $1=3$, df $2=11$, f- hitung =9,028 dan f-tabel $=3,9823$ jadi kriterianya jika $\mathrm{f}$ hitung $>\mathrm{F}$ tabel $=(9,028>3,9823)$, maka dapat di simpulkan bahwa semua variabel independen (BOPO, NPL dan LDR) secara simultan berpengaruh terhadap vriabel dependen ( ROA ).

\subsection{Pembahasan Hasil Penelitian}

Pada sub bab pembahasan ini akan dibahas mengenai hal yang berkaitan dengan jawaban hipotesis penelitian. Hasil pengujian hipotesis tersebut di jelaskan sebagai berikut :

\subsubsection{Pengaruh BOPO Terhadap ROA.}

Hasil dari penelitian menunjukkan bahwa variabel BOPO memiliki koefisien regresi negatif sebesar -0,066 dengan tingkat signifikansi sebesar -0,029. Tingkat signifikansi tersebut lebih kecil dari 0,05 $(-0,029<0,05)$ dan nilai t-hitung lebih besar dari t-tabel $(2,506<2,20099)$. Dengan demikian, dapat disimpulkan bahwa BOPO berpengaruh negatif terhadap ROA. 


\subsubsection{Pengaruh NPL terhadap ROA.}

Hasil dari penelitian menunjukkan bahwa variabel NPL memiliki koefisien regresi negatif sebesar -0,067 dengan tingkat signifikansi sebesar 0.729. Tingkat signifikansi tersebut lebih besar dari 0,05 $(0,729>0,05)$. dan nilai t-hitung lebih kecil dari t-tabel $(-0,355<2,20099)$. Dengan demikian, dapat disimpulkan bahwa NPL secara parsial tidak berpengaruh signifikan terhadap ROA.

\subsubsection{Pengaruh LDR terhadap Tingkat Profitabilitas bank.}

Hasil Penelitian menunjukkan bahwa variabel LDR memiliki koefisien regresi positif sebesar 0,015 dengan tingkat signifikansi sebesar 0,036 lebih kecil dari 0,05 $(0,036<0,05)$ dan nilai t-hitung lebih besar dari t-tabel $(2,887>2,20099)$. Dengan demikian, dapat ditarik kesimpulan bahwa LDR secara parsial berpengaruh positif terhadap ROA.

\subsubsection{Pengaruh BOPO, NPL, LDR terhadap ROA.}

Hasil uji statistik f menunjukkan nilai signifikansi lebih kecil dari 0,05 yaitu 0,003 < 0,05. Dengan df $1=3$ dan df $2=11$, f-hitung $=9,028$ lebih besar dari f-tabel $=3,9823(9,028>$ 3,9823), maka H4 Dapat di simpulkan bahwa semua variabel independen (BOPO, NPL dan LDR) secara simultan berpengaruh positif terhadap vriabel dependen.( ROA ).

\subsubsection{Determinasi $\left(R^{2}\right)$}

Tabel 9

Determinasi $\left(\mathbf{R}^{2}\right)$

\section{Uji Koefesien Determinasi $\left(R^{2}\right)$}

Model Summaryb

\begin{tabular}{|l|c|c|c|c|}
\hline Model & $\mathrm{R}$ & $\begin{array}{c}\mathrm{R} \\
\text { Square }\end{array}$ & $\begin{array}{c}\text { Adjusted } \mathrm{R} \\
\text { Square }\end{array}$ & $\begin{array}{l}\text { Std. Error of } \\
\text { the Estimate }\end{array}$ \\
\hline 1 & .843 & .711 & .632 & .851 \\
\hline
\end{tabular}

a. Predictors: (Constant), LDR, BOPO, NPL

b. Dependent Variable: ROA

Koefisien determinasi atau $\mathrm{R}^{2}$ merupakan kemampuan prediksi dari ketiga variabel independen (BOPO NPL dan LDR) terhadap variabel dependen (ROA). $\mathrm{R}$ square adalah 0,711. ( $0,711 \times 100=71,1 \%)$ Hal ini berarti $71,1 \%$ ROA dipengaruhi oleh variabel independen (BOPO,NPL,LDR) Selebihnya yaitu 29,9\% ROA dipengaruhi faktor lain yang belum diteliti dalam penelitian ini.

\section{KESIMPULAN}

Berdasarkan analisis yang telah dilakukan terhadap 3 (Tiga) BPR NTB Konvensional di kabupaten Lombok Timur pada tahun 2013-2017 dapat disimpulkan bahwa:

1. Hasil dari penelitian menunjukkan bahwa variabel BOPO memiliki koefisien regresi negatif sebesar $-0,066$ dengan tingkat signifikansi sebesar 0,029. Tingkat signifikansi tersebut lebih kecil dari 0,05 $(0,029<0,05)$ dan nilai t-hitung lebih besar dari t-tabel $(2.506$ $>$ 2,20099). Dengan demikian, dapat disimpulkan bahwa secara parsial BOPO 


\section{Jurnal Magister Manajemen Unram}

\section{NATIONALLY ACCREDITED J OURNAL - DECREE NO. 21/E/KPT/2018}

berpengaruh Negatif dan signifikan terhadap ROA. pada bank BPR Konvesional Lombok Timur tahun 2013-2017, artinya jika nilai BOPO mengalami peningkatan maka nilai ROA akan menurun dan sebaliknya.

2. Hasil dari penelitian menunjukkan bahwa variabel NPL memiliki koefisien regresi negatif sebesar -0,067 dengan tingkat signifikansi sebesar 0.729. Tingkat signifikansi tersebut lebih besar dari 0,05 $(0,729>0,05)$. dan nilai t-hitung lebih kecil dari t-tabel $(-0,355<$ 2,20099). Dengan demikian, dapat disimpulkan bahwa NPL secara parsial tidak ada pengaruh terhadap ROA. pada bank BPR Konvesional kabupaten Lombok Timur Tahun 2013-2017.

3. Hasil Penelitian tersebut menunjukkan bahwa variabel LDR memiliki koefisien regresi positif sebesar 0,015 dengan tingkat signifikansi sebesar 0,036 lebih kecil dari 0,05 $(0,036<$ $0,05)$ dan nilai t-hitung lebih besar dari t-tabel $(2,887>2,20099)$. Dengan demikian, dapat disimpulkan bahwa secara parsial LDR berpengaruh positif terhadap ROA. pada bank BPR Konvesional Kabupaten Lombok Timur Tahun 2013-2017.

4. Semua variabel independen (BOPO, NPL dan LDR) secara simultan berpengaruh positif terhadap vriabel dependen (ROA), pada bank BPR Konvesional Kabupaten Lombok Timur Tahun 2013-2017. Dimana hasil uji statistik f menunjukkan nilai signifikansi lebih kecil dari 0,05 yaitu 0,003 $<0,05$. Dengan df $1=3$ dan df $2=11$, f-hitung $=9,028$ dan f-tabel $=$ 3,9823 Jadi $\mathrm{F}$ hitung $<\mathrm{F}$ tabel $=9,028<3,9823$.

\section{DAFTAR PUSTAKA}

Anonim, (2012) Undang - undang No, 10 tentang Perbankan, 1998. http:/ / komisiinformasi,go,id/ assets/data/arsip/uu-bank-10-1998,10 Nopember 1998, Diakses pada tanggal 21 Juli 2012.

Dendawijaya, L.. 2009. Manajemen Perbankan, Jakarta: Ghalia Indonesia, 2003. Perbankkan dan Manajemen Keuangan. Ghalia Indonesia. Jakarta.

Hasan, 2014. manajemen prekonomian Indonesia Jakarta : PT, Gramedia Pustaka Umum. Ikatan Akuntan Keuangan Indonesia (IAI), SAK No, 31 Revisi 2012, Jakarta.

Kasmir. 2014. Bank dan Lembaga Keuangan Lainnyā, PT :Raja Grafindo Frasada. Jakarta Munawir. 2004. Dasar Akuntansi Perbankan. Jakarta :PT :Raja Grafindo Frasada.

Prilliana, S. 2012 Analisis Risiko Kredit, Skripsi, Universitas Pendidikan Indonesia,mataram. Rivai, dkk. 2005. Credit Management Hanbook, Jakarta: Rajawali Pers.

Sartono, A. 2008. Manajemen Keuangan Teori dan Aplikasi, Yogyakarta: BPFE. Surat Edaran BI No, 3/30/DPNP/2011.

Sugiyono. 2011. Metode Penelitian Manajemen.Bandung: CV Alfabeta.

2013. Metode penelitian kantitatif kualitatif dan penelitian tindakan. Bandung: CV Alfabeta. 